九州大学学術情報リポジトリ

Kyushu University Institutional Repository

\title{
An Experimental Study on Adhesive Condition with Sugi Block Specimen which Assumed Finger- joint by Block Shear Test
}

Ohuchi, Takeshi

Laboratory of Woodworking, Department of Technology, Fukuoka University of Education

Hermawan, Andi

Laboratory of Wood Material Technology, Sustainable Bioresources Science, Department of Agroenvironmental Sciences, Faculty of Agriculture, Kyushu University

Fuj imoto, Noboru

Laboratory of Wood Material Technology, Sustainable Bioresources Science, Department of Agroenvironmental Sciences, Faculty of Agriculture, Kyushu University

https://doi.org/10.5109/26167

出版情報: 九州大学大学院農学研究院紀要. 58 (1)，pp.99-102，2013-02. Faculty of Agriculture， Kyushu University

バージョン :

権利関係 : 


\title{
An Experimental Study on Adhesive Condition with Sugi Block Specimen which Assumed Finger-joint by Block Shear Test
}

\author{
Takeshi OHUCHI ${ }^{1 *}$, Andi HERMAWAN ${ }^{2 *}$ and Noboru FUJIMOTO ${ }^{2 *}$ \\ Laboratory of Wood Material Technology, Sustainable Bioresources Science \\ Department of Agro-environmental Sciences, Faculty of Agriculture, \\ Kyushu University, Fukuoka 812-8581, Japanese \\ (Received October 31, 2012 and accepted November 8, 2012)
}

\begin{abstract}
In end-jointing of laminae for the glulam timber, finger-joint is generally used. However, the strength properties of the glulam timber greatly decrease by slippage-off and destruction in starved joints of fingerjointed part when the laminae with starved joints in the finger-joint are located on the external layer of the glulam timber. Therefore, for the glulam timber with good strength properties, the evaluation of finger-joint properties after finger-jointing is important, and the method is hoped to be simple and non-destructive.

In this study, to examine the optimum adhesive condition in finger-joint part which influences strength properties of the large-scale sugi finger-jointed laminae, the block shear tests with sugi block specimens which assumed finger-joint part and glued under various adhesive conditions was performed. The main results are summarized as follows: In the case of the specimen of W-O (With curing agent, One side spreading) under 40-20 (open assembly temperature and time set to $40^{\circ} \mathrm{C}$ and $20 \mathrm{~min}$ ) with resorcinol phenol resin type adhesive, the tendency to decrease of the shear strength was shown. From the fracture morphology, the reason was considered that the adhesive did not transfer on none-spreading side because the surface of the adhesive has stiffened by setting the open assembly temperature and time. In other conditions, an enough glued performance was considered because the shear strength showed a comparatively large value. Moreover, in the case of None-specimen (Without curing agent), the shear strength shows a small value and the tendency to decrease was shown by setting the open assembly temperature and time. In three conditions of W-O, None-B (Without curing agent, Both sides spreading), and None-O (Without curing agent, One side spreading) under 40-20 with aqueous polymer solution-isocyanate adhesive, the shear strength had decreased remarkably. In other conditions, the difference was not admitted and the tendency to decrease of the shear strength was shown by setting the open assembly temperature and time.
\end{abstract}

Key words: aqueous polymer solution-isocyanate, block shear test, fracture morphology, open assembly temperature and time, resorcinol-phenol resin

\section{INTRODUCTION}

Recently, the glulam timber has the characteristics which can be manufactured heavy section and large-scale by laminating the end-jointed laminae to secure the length needed as materials for large wooden buildings. In this end-jointing of laminae, finger-joint is generally used. Therefore, for the glulam timbers with good strength properties, the evaluation of finger-joint properties after finger-jointing is important.

In our previous studies, we paid attention to acoustic emission (AE) as a non-destructive method, and bending test for finger-jointed laminae with starved joints has been performed. AE generated during bending test has also been investigated. From these obtained results, AE technique was promising for the detection of starved joints in the finger-joint at the early stage of the bending test (Ohuchi et al., 2004; Yano et al., 2007). In addition, we clarified that the position of starved joints in fingerjoint could be presumed by one-dimensional method of

${ }^{1}$ Laboratory of Woodworking, Department of Technology, Fukuoka University of Education, Munakata City 811-4192, Japan

${ }^{2}$ Laboratory of Wood Material Technology, Sustainable Bioresources Science, Department of Agro-environmental Sciences, Faculty of Agriculture, Kyushu University, Fukuoka City 812-8581, Japan

* Corresponding author (E-mail: tohuchi@fukuoka-edu.ac.jp) using AE signal (Ohuchi et al., 2009; Sato et al., 2009). However, the influence that the adhesive condition in finger-jointing effects on the strength properties of fingerjointed laminae had been hardly examined.

In this study, to examine the optimum adhesive condition in finger-jointed part which influences strength properties of the large-scale sugi (Japanese cedar, Cryptomeria japonica D. Don) finger-joint laminae, the sugi block specimens which assumed finger-joint and glued under various adhesive conditions was prepared, and the block shear tests were performed.

\section{MATERIALS AND METHODS}

\section{Specimens}

Specimens used in this study were made from sugi (Japanese cedar, Cryptomeria japonica D. Don). The mean specific gravities and the mean moisture contents of specimens were 0.38 and $10.0 \%$, respectively. The size of specimen for the block shear test was $25 \mathrm{~mm}$ wide, $10 \mathrm{~mm}$ thick, and $30 \mathrm{~mm}$ long.

\section{Adhesive condition}

Adhesive for wood in this study was used the resorcinol phenol resin type adhesive (RPR) and the aqueous polymer solution-isocyanate adhesive (API), respectively. The adhesive conditions in this study were shown in Table 1. Under the adhesive conditions as shown in 
Table 1. Adhesive conditions in this study

\begin{tabular}{|c|c|c|c|c|}
\hline Adhesive & Curing agent & Spread side & Open assembly temperature and time & End press \\
\hline \multirow[t]{2}{*}{$\begin{array}{c}\text { Resorcinol phenol resin } \\
\text { type adhesive } \\
\text { (RPR) }\end{array}$} & $\begin{array}{l}\text { With } \\
\text { Curing agent } \\
\text { (W) }\end{array}$ & $\begin{array}{l}\text { Both sides } \\
\text { (B) }\end{array}$ & Room temperature, 0 min $(\mathrm{N})$ & \\
\hline & & & $20^{\circ} \mathrm{C}, 20 \min (20-20)$ & $5.0 \mathrm{kgf} / \mathrm{cm}^{2}$ \\
\hline $\begin{array}{l}\text { Aqueous polymer solution- } \\
\text { isocyanate adhesive } \\
\text { (API) }\end{array}$ & $\begin{array}{l}\text { Without } \\
\text { Curing agent } \\
\text { (None) }\end{array}$ & $\begin{array}{l}\text { One side } \\
\text { (O) }\end{array}$ & $40^{\circ} \mathrm{C}, 20 \min (40-20)$ & \\
\hline
\end{tabular}

Table 1 , to set the shear area to $625 \mathrm{~mm}^{2}$, the adhesive was spread on the area of $25 \mathrm{~mm}$ wide and $25 \mathrm{~mm}$ long of the specimen and end pressed at $5.0 \mathrm{kgf} / \mathrm{cm}^{2}$. The block specimens were cured under the room temperature for more 48 hours after adhesion. Figure 1 shows the schematic diagram of the block specimen. Eight block specimens were prepared for each condition.

In these adhesive conditions as shown in Table 1, the block specimen end pressed by using resin combined with curing agent was assumed as W-specimen. The other block specimen end pressed by using resin without curing agent was assumed as None-specimen. In the case of spreading on the both sides of the specimens before pressing was assumed as B-specimen. In the case of spreading on the one side of the specimens before press-
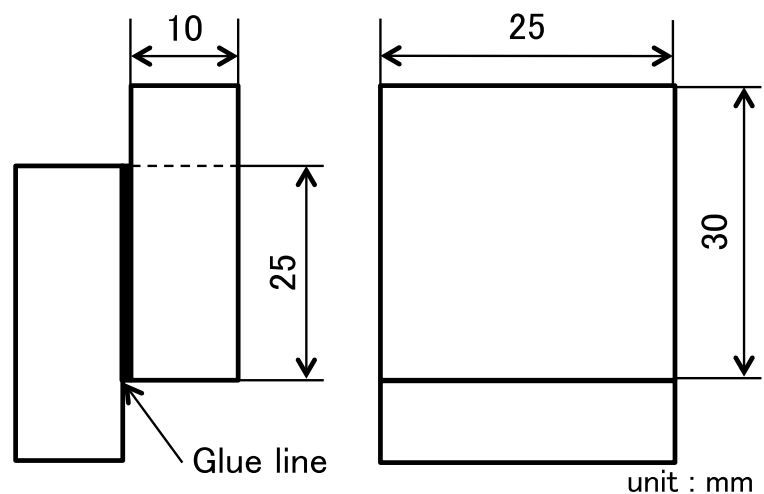

Fig. 1. Schematic diagram of block specimen used in this study.

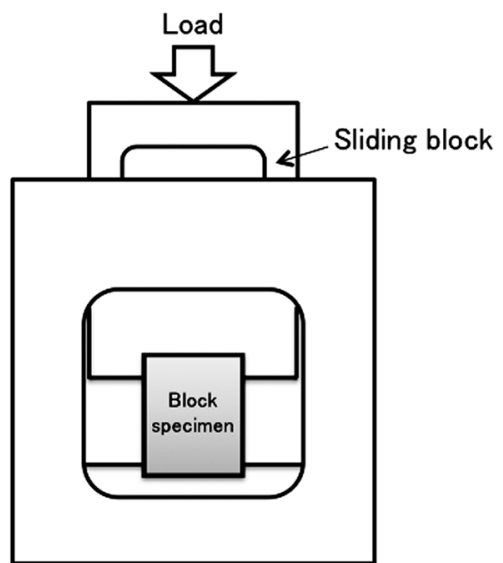

Fig. 2. Schematic diagram of jig for shear test used in this study. ing was assumed as O-specimen. The open assembly temperature and time after spreading means the time and temperature until the specimens were glued.

\section{Block shear test}

The block shear tests were performed based on the Japanese Industrial Standard methods (JIS Z 2101). Figure 2 shows the schematic diagram of the block shear test. The loading speed was set to $1.2 \mathrm{~mm} / \mathrm{min}$.

\section{RESULTS AND DISCUSSION}

\section{Fracture morphology}

Figure 3-6 show the fracture morphology in glue line of the block specimens glued with RPR adhesive after the block shear tests. In the case of specimen of $\mathrm{W}-\mathrm{D}$, the wood failure was admitted in most block specimens. However, in the case of specimen of W-S, the fracture in the interface or the glue line of the block specimens that the open assembly temperature and time set to $40^{\circ} \mathrm{C}$ and 20 min (40-20) were admitted. Therefore, it became clear that the adhesive failure due to the difference of the conditions was occurred. Moreover, the transfer of the adhesive on none-spreading side was not admitted in this condition. It was considered that the surface of the adhesive has stiffened by setting the open assembly temperature and time. In the case of None, $\mathrm{W}-$ and $\mathrm{O}-$-specimen (a) $\mathrm{N}$

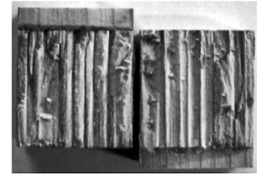

(b) $20-20$

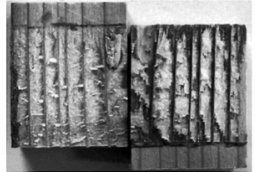

(c) $40-20$

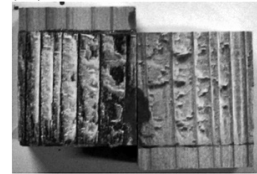

Fig. 3. Fracture morphology in glue line of block specimen with RPR.

(W-B; With curing agent, Both sides spreading) (a) $\mathrm{N}$

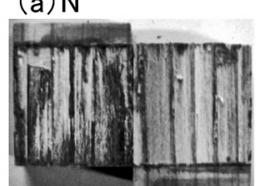

(b) $20-20$

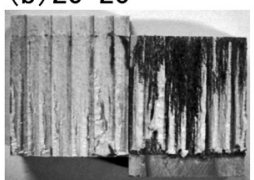

(c) $40-20$

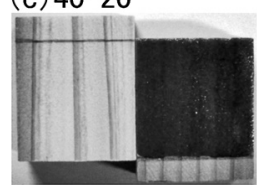

Fig. 4. Fracture morphology in glue line of block specimen with RPR. (W-O; With curing agent, One side spreading) 
(a) $\mathrm{N}$

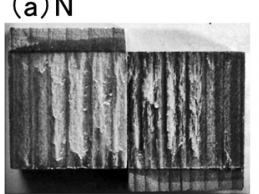

(b) $20-20$

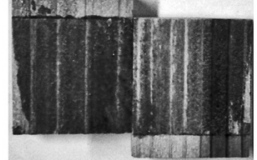

(c) $40-20$

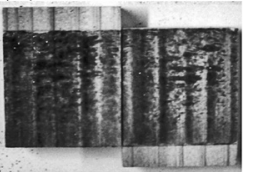

Fig. 5. Fracture morphology in glue line of block specimen with RPR.

(None-B; Without curing agent, Both sides spreading)

(a) $\mathrm{N}$

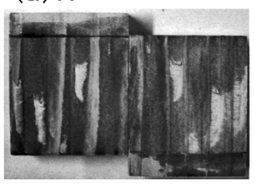

(b) $20-20$

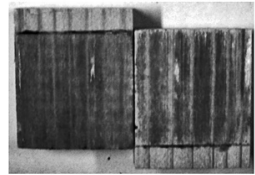

(c) $40-20$

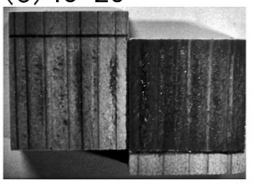

Fig. 6. Fracture morphology in glue line of block specimen with RPR.

(None-O; Without curing agent, One side spreading)

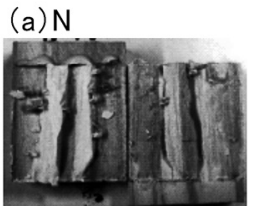

(b) $20-20$

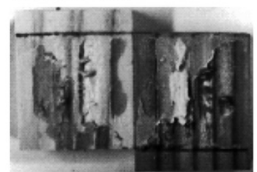

(c) $40-20$

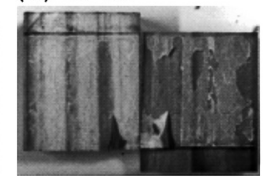

Fig. 7. Fracture morphology in glue line of block specimen with API.

(W-B; With curing agent, Both sides spreading)

(a) $\mathrm{N}$

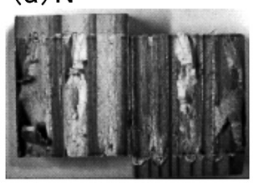

(b) $20-20$

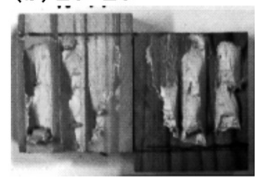

(c) $40-20$

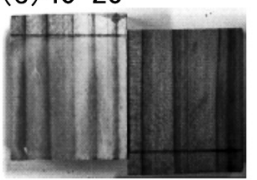

Fig. 8. Fracture morphology in glue line of block specimen with API.

(W-O; With curing agent, One side spreading)

(a) $\mathrm{N}$

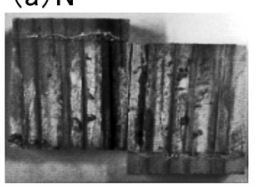

(b) $20-20$

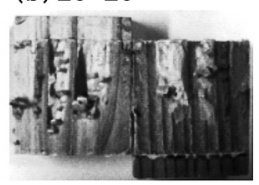

(c) $40-20$

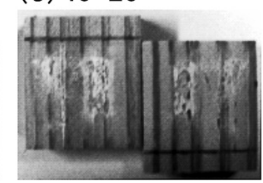

Fig. 9. Fracture morphology in glue line of block specimen with API.

(None-B; Without curing agent, Both sides spreading)

(a) $\mathrm{N}$

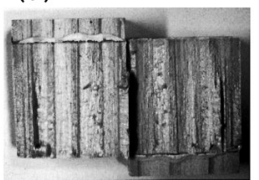

(b) $20-20$

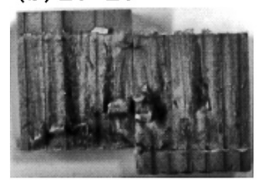

Fig. 10. Fracture morphology in glue line of block specimen with API.

(None-O; Without curing agent, One side spreading) showed a similar tendency and the fracture in the interface or the glue line of the block specimen was admitted in most specimens. Especially, this tendency was shown remarkably in the condition of setting the open assembly temperature and time.

Figure 7-10 show the fracture morphology on the specimen glued with API adhesive after the block shear tests. In three conditions of $\mathrm{W}-\mathrm{O}$, None-D, and None-O under 40-20, the fracture in the interface or the glue line of the block specimens was admitted. In other conditions, the wood failure was admitted in most specimens.

\section{Shear strength}

Figure 11 shows the shear strength in each adhesive condition with RPR. In the case of the specimens of W-B, the shear strength showed a large value, and the difference by the difference of the open assembly conditions was not admitted. In the case of the specimens of $\mathrm{W}-\mathrm{O}$, the shear strength had decreased in the condition of 40-20. From the above-mentioned fracture morphology, it is considered that the adhesive did not transfer on non-spreading side because the surface of the adhesive

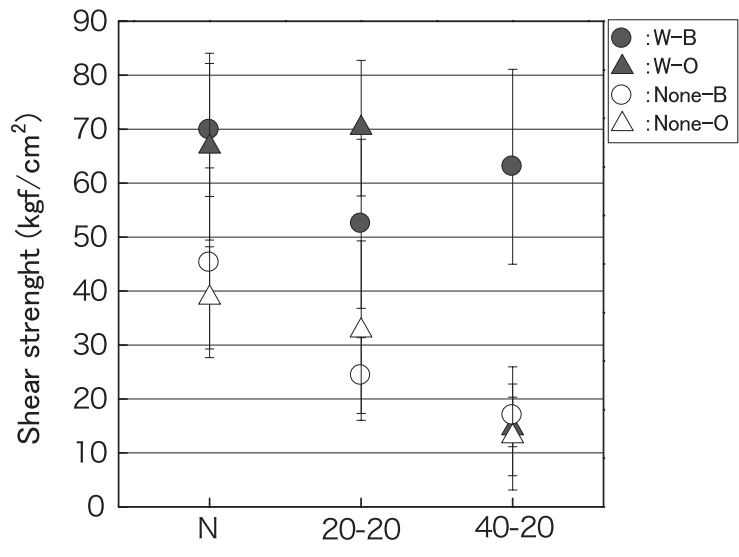

Open assembly temperature $\left({ }^{\circ} \mathrm{C}\right)$ and time $(\min )$

Fig. 11. Shear strength in each adhesive condition with RPR.

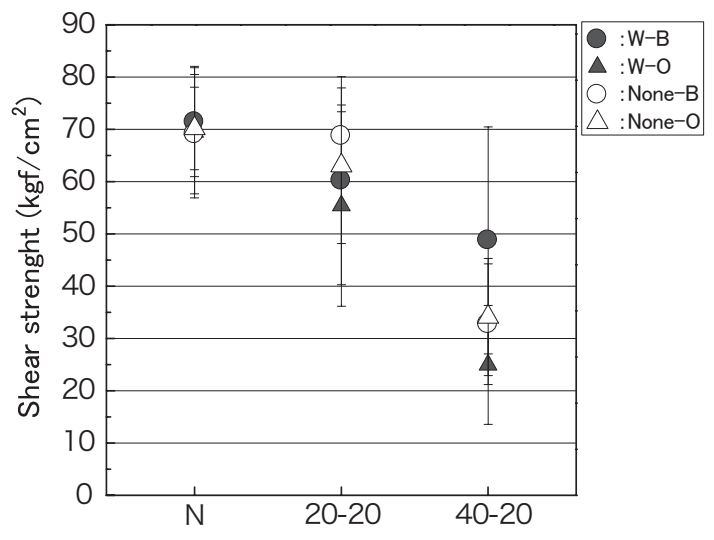

Open assembly temperature $\left({ }^{\circ} \mathrm{C}\right)$ and time $(\mathrm{min})$

Fig. 12. Shear strength in each adhesive condition with API. 
has stiffened by setting the open assembly temperature and time. Moreover, in the case of the specimens of None, the tendency of both B- and O-specimen was similar, and the shear strength showed a small value, and the tendency to decrease was shown by setting the open assembly temperature and time.

Figure 12 shows the shear strength in each adhesive condition with API. In three conditions of $\mathrm{W}-\mathrm{O}$, None-B, and None-O under 40-20, the shear strength had decreased. In other conditions, the difference was not admitted in most specimens and the tendency to decrease was shown by setting the open assembly temperature and time.

\section{CONCLUSIONS}

In this study, to examine the optimum adhesive condition in finger-joint part which influences strength properties of the large-scale sugi finger-joint laminae, the block shear tests with glued sugi specimens under various adhesive conditions was performed. The main results are summarized as follows:

In the case of the specimen of $\mathrm{W}-\mathrm{O}$ (With curing agent, One side spreading) under 40-20 (the open assembly temperature and time set to $40^{\circ} \mathrm{C}$ and $20 \mathrm{~min}$ ) with resorcinol phenol resin type adhesive, the tendency to decrease of the shear strength was shown. From the fracture morphology, it was considered that the adhesive did not transfer on non-spreading side because the surface of the adhesive has stiffened by setting the open assembly temperature and time. In other conditions, an enough glued performance was considered because the shear strength showed a comparatively large value. Moreover, in the case of specimen of None (Without curing agent), the shear strength shows a small value and the tendency to decrease was shown by setting the open assembly temperature and time.

In three conditions of $\mathrm{W}-\mathrm{O}$, None-B (Without curing agent, Both sides spreading), and None-O (Without curing agent, One side spreading) under 40-20 with aqueous polymer solution-isocyanate adhesive, the shear strength had decreased remarkably. In other conditions, the difference was not admitted in most specimens and the tendency to decrease of the shear strength was shown by setting the open assembly temperature and time.

\section{REFERENCES}

Ohuchi T, Ando M, Fujimoto Y, Morita , Fujimoto N, Murase Y (2004) Non-destructive evaluation of strength properties of sugi finger-jointed laminae (in Japanese). The summary of the 22nd Wood Technological Association of Japan (Osaka): 85-86

Ohuchi T, Murakami Y, Fujimoto N (2009) Evaluation of fingerjointed laminae for glulam timber by acoustic emission I Development of jig for acoustic emission sensor installed to production line and its verification test. Journal of the Faculty of Agriculture Kyushu University, 54(2): 467-470

Sato E, Ohuchi T, Fujimoto N (2009) Evaluation of finger-jointed laminae for glulam timber by acoustic emission II Development of evaluation system for finger-jointed laminae with starved joints. Journal of the Faculty of Agriculture Kyushu University, 54(2): 471-475

Yano K, Ohuchi T, Murase Y, Fujimoto Y, Morita H (2007) Evaluation of sugi finger-jointed laminae with a knot and starved joints by acoustic emission. Journal of the Faculty of Agriculture Kyushu University, 52(1): 111-116 